\title{
PENERAPAN MODEL SINEKTIK UNTUK MENINGKATKAN KEMAMPUAN MENULIS CERPEN BAGI MAHASISWA
}

\author{
Muhammad Noor Ahsin ${ }^{1}$, Ristiyani ${ }^{2}$ \\ noor.ahsin@umk.ac.id ${ }^{1}$, ristiyani@umk.ac.id ${ }^{2}$
}

\author{
${ }^{1}$ Program Studi Pendidikan Bahasa dan Sastra Indonesia \\ FKIP Universitas Muria Kudus \\ ${ }^{2}$ Program Studi Pendidikan Bahasa dan Sastra Indonesia \\ FKIP Universitas Muria Kudus
}

\begin{abstract}
Abstrak
Keterampilan menulis merupakan keterampilan yang perlu dimiliki mahasiswa program studi PBSI (Pendidikan Bahasa dan Sastra Indonesia). Dalam pembelajaran mata kuliah Ekspresi Tulis Sastra Program Studi PBSI Universitas Muria Kudus, mahasiswa diharapkan bisa menulis karya sastra, misalnya menulis cerpen. Permasalahannya, menulis cerita pendek masih dirasa menjadi hal yang susah. Mahasiswa masih merasa berat dan kesulitan menulis cerita pendek. Penelitian ini bertujuan pertama menjelaskan peningkatan keterampilan menulis cerita pendek mahasiswa PBSI dengan model sinektik berkonteks multikultural pada mata kuliah ekspresi tulis sastra. Kedua, menjelaskan sikap mahasiswa dalam pembelajaran menulis cerita pendek dengan model sinektik berkonteks multikultural. Metode yang digunakan dalam penelitian ini menggunakan desain penelitian tindakan kelas yang dilaksanakan selama dua siklus. Proses pengumpulan data dilakukan melalui teknik tes, berupa tugas untuk menulis cerita pendek. Hasil penelitian yang dilakukan menunjukkan adanya bukti peningkatan keterampilan dalam menulis cerita pendek siklus I rata-rata $60,42 \%$, sedangkan pada siklus II naik menjadi 80,18 $\%$. Sehingga dapat disimpulkan penggunaan model sinektik efektif untuk meningkatkan kemampuan menulis cerita pendek bagi mahasiswa.
\end{abstract}

Kata kunci: cerpen, menulis, model sinektik.

\begin{abstract}
Writing skills are skills that need to be possessed by PBSI (Indonesian Language and Literature Education) study program students. In studying Literature Expression Writing courses in the PBSI Study Program at Muria Kudus University, students are expected to be able to write literary works, for example writing short stories. The problem is, writing short stories is still considered to be a difficult thing. Students still feel heavy and have difficulty writing short stories. This study aims at first explaining the improvement of Indonesian Language and Literature Education study program students' short story writing skills with a social synectic model with a multicultural context in the subject of literary expression. Second, explaining the attitude of students in learning to write short stories with a social synectic model with a multicultural context. The method used in this study used a class action research design which was carried out for two cycles. The process of collecting data is done through test techniques, in the form of assignments to write short stories. The results of research conducted showed evidence of increased skills in writing short stories in the first cycle of an average of 60.42\%, while in the second cycle rose to $80.18 \%$. So it can be concluded the use of effective synectic models to improve the ability to write short stories for students.
\end{abstract}

Keywords: short stories, synectic models, writing.

\section{PENDAHULUAN}

Indonesia merupakan negara yang multikultural. Terdiri dari beragam budaya dan etnis yang berbeda. Selain itu, Indonesia juga kaya akan suku, agama, ras, dan warna kulit yang berbeda. Hal itu menunjukkan kalau Indonesia merupakan negara yang multikultural. Untuk menjaga eksistensi dalam berbangsa dan bernegara, tentu masing-masing pihak perlu menjaga diri dan menghormati antarsatu dengan yang lainnya.

Menjadi negara yang multikultural tentu harus disyukuri dan masing-masing pihak harus menjunjung tingggi toleransi. Toleransi merupakan sikap yang harus dipunyai setiap individu atau kelompok. Sikap ini sangat penting karena dengan memiliki sikap toleransi tentu akan berdampak positif bagi bangsa dan negara kita.

Negara Indonesia yang beragam ini perlu kita jaga. Keragaman atau perbedaan adalah sebuah kekuatan yang harus dijaga. Meskipun demikian untuk menjaga sikap saling menghormati dan sikap toleransi tentu tidak mudah. Hal itu karena keragaman juga bisa menimbulkan sesuatu

148 | Jurnal Kredo

Vol. 3 No. 1 Oktober 2019 
yang negatif apabila tidak dijaga atau saling menjaga dengan baik.

Keragaman budaya dan etnis tidak jarang menimbulkan adanya berbagai konflik di Indonesia. Kurangnya pemahaman masyarakat tentang multikulturalisme, tidak jarang menimbulkan perpecahan dan pertikaian bangsa di berbagai tempat. Untuk itu perlu penanaman nilai multikultural pada segenap masyarakat termasuk mahasiswa, salah satunya melalui penulisan karya sastra berwawasan multikultural. Langkah ini kiranya perlu dilakukan sebagai upaya memberikan pemahaman nilai-nilai multikultural melalui karya sastra.

Pendidikan multikultural merupakan suatu proses penanaman nilai-nilai kepada anak didik, sehingga mereka dapat memahami identitas diri dan menerima perbedaan-perbedaan sosiokultural sebagai hal yang alamiah serta mengembangkan kemampuan untuk berkomunikasi, berbagi, dan bekerja sama dengan orang lain (Pramujiono, 2015).

Dalam konteks ini, perlu kiranya pembelajaran penulisan karya sastra, khususnya pembelajaran menulis cerpen dapat diarahkan untuk menulis tema multikultural. Dengan harapan agar peserta didik lebih memahami perbedaan dan pluralisme yang ada di Indonesia untuk meminimalisir perpecahan bangsa.

Keterampilan menulis sastra khususnya menulis cerpen perlu dimiliki mahasiswa. Terlebih bagi mahasiswa yang mengambil bahasa dan sastra. Dengan memiliki keterampilan menulis cerpen tentu ke depan akan menjadi keterampilan yang penting untuk menunjang ketika nanti sudah menjadi guru bahasa dan sastra Indonesia.

Keterampilan menulis itu penting. Melalui kegiatan menulis seseorang dapat menuangkan pikiran, ide, maupun perasaannya dalam bentuk tulisan (Ahsin 2016).

Selain itu, saat menjadi mahasiswa pun keterampilan menulis karya sastra sangat penting sekali. Dengan memiliki keterampilan menulis karya sastra tentu nanti diharapkan akan memberikan dampak yang positif bagi mahasiswa.

Keterampilan menulis cerita pendek merupakan keterampilan yang perlu dimiliki mahasiswa program studi Pendidikan Bahasa dan Sastra Indonesia. Dalam mata Kuliah Ekspresi Tulis sastra, mahasiswa diharapkan bisa menulis karya sastra, salah satunya menulis cerita pendek.

Cerita pendek atau biasa disebut cerpen merupakan sebuah karya sastra yang berwujud prosa, karangan bebas yang berisi cerita yang di dalamnya ada konflik, yang biasanya habis dibaca sekali duduk. Dengan kata lain, cerita yang ditulis pendek.

Meskipun ceritanya pendek, akan tetapi banyak masyarakat yang menyukai genre karya sastra cerpen. Di beberapa media cetak, khususnya hari Minggu pun banyak yang redaksi yang memberi ruang sastra untuk dimuat, misalnya puisi dan juga cerpen. Cerita pendek dapat kita jumpai di beberapa media yang biasanya terbit setiap hari Minggu.

Selain media cetak, tidak sedikit media online yang juga memberikan ruang untuk penulis karya sastra. khususnya cerpen untuk diterbitkan secara online. Tentunya dengan syarat dan aturan tertentu yang biasanya tiap media online memiliki aturan dan ketentuan masing-masing.

Satu hal yang perlu dicermati adalah bahwa ide atau tema menulis cerpen bisa diawali dari sebuah kisah nyata, bahkan yang dialami sendiri oleh penulis. Ini berarti bahwa tema tidak selalu berangkat dari sebuah khayalan atau imajinasi penulis, melainkan bisa berangkat dari halhal yang dialami secara nyata oleh penulis. Untuk itu, perlu kiranya dicari satu cara yang tepat agar mahasiswa dapat memiliki kemampuan menulis cerita pendak yang baik (Setyaningsih, 2010).

Saat proses perkuliahan mata kuliah ekspresi tulis sastra dalam praktiknya mahasiswa masih banyak yang merasa kesulitan ketika diminta menuangkan ide 
dalam menulis karya sastra, seperti menulis cerita pendek. Mereka belum terbiasa menulis cerita pendek. Kalau pun ada yang sudah pernah menulis cerita pendek, hasilnya pun bisa dikatakan masih belum memuaskan. Bisa disimpulkan kualitas karya mereka masih kurang baik, dan perlu disempurnakan agar leboh bagus dan lebih menarik. Padahal menulis cerita pendek merupakan keterampilan penting yang perlu dimiliki oleh mahasiswa, khususnya calon guru bahasa Indonesia.

Meskipun menulis itu tidak mudah, tapi asalkan dibiasakan untuk menulis nanti juga bisa menulis. Menulis cerpen pun demikian. Bagi yang sudah pernah bisa menulis, tentu tidak menjadi masalah ketika diminta menulis. Tapi ketika jarang menulis, dan kemudian diminta menulis, itu bisa menjadi salah satu pekerjaan yang berat.

Berdasarkan permasalahan yang terjadi tersebut, maka perlu dicarikan solusi untuk mengatasinya. Hal yang perlu dilakukan adalah mahasiwa perlu diberi bimbingan menulis cerpen yang intensif. Mereka bisa menulis cerpen berdasarkan pengalaman diri sendiri atau berdasarkan pengalaman orang lain. Hal ini penting untuk memberikan bekal agar mereka bisa menulis cerita pendek yang bersumber dari ide diri sendiri atau ide dari orang lain. Misalnya menulis cerita pendek dengan tema multikulturalisme.

Selain itu, solusi lainnya adalah perlu menerapkan metode pembelajaran yang kreatif dan inovatif dalam menulis cerita pendek. Dalam pembelajaran menulis cerita pendek ini, akan dicoba menerapkan model pembelajaran sinektik. Penerapan model ini diharapkan menjadi solusi untuk mendapatkan hasil pembelajaran menulis cerpen yang lebih baik.

Berdasarkan permasalahan latar belakang tersebut, maka rumusan permasalahan yang diangkat adalah pertama, bagaimana penerapan model sinektik berkonteks multikultural untuk meningkatkan kemampuan menulis cerpen bagi mahasiswa? Kedua, bagaimana sikap dan perilaku mahasiswa dalam proses pembelajaran menulis cerita pendek dengan menggunakan model sinektik pada mata kuliah ekspresi tulis sastra?

\section{KAJIAN TEORI}

Cerita pendek adalah suatu cerita yang relatif pendek, singkat, jika dikaitkan dengan genre cerita hanya memiliki efek tunggal tanpa mengubah nasib pelaku dan dapat dibaca sekali duduk (Zulaiha 2016). Secara etimologis cerita pendek pada dasarnya adalah karya sastra fiksi atau sesuatu yang dikonstruksikan, ditemukan, dibuat atau dibuat-buat. Hal tersebut berarti bahwa cerita pendek tidak terlepas dari fakta. Fiksi merujuk pada pengertian rekaan atau konstruksi dalam cerita pendek terdapat pada unsur fisiknya. Sementara fakta yang merujuk pada realitas dalam cerpen terkandung dalam temanya. Dengan demikian dapat dipahami, cerpen disusun berdasarkan fakta yang dialami atau dirasakan oleh penulisnya. (Nuryatin, 2016).

Dari pendapat tersebut dapat disimpulkan bahwa cerpen merupakan salah satu bentuk karya sastra yang ditulis dengan pendek, yang didalamnya menyuguhkan cerita yang berisi konflik. Konflik yang terdapat dalam cerpen sangat diperlukan karena cerpen tanpa konflik tentu akan menjadi kurang menarik bagi pembaca.

Dalam menulis cerita pendek, biasanya tokoh yang ada dalam cerita tidak banyak. Dengan kata lain tokoh yang ada dalam cerita bisa dikatakan sedikit. Cerpen tentu berbeda dengan karya sastra lainnya seperti novel. Dalam novel masalah lebih banyak, rumit, dan kompleks. Dalam cerpen masalah yang ditampilkan tidak sebanyak dan sekompleks seperti dalam novel.

Sebuah cerpen yang baik adalah cerpen yang merupakan suatu kesatuan bentuk, utuh, manunggal, tak ada bagian-bagian yang tak perlu, tetapi juga tak ada sesuatu yang terlalu banyak, semuanya pas, integral dan mengandung suatu arti. 
Cerpen harus memberi gambaran sesuatu yang tajam. Inilah kelebihan bentuk cerpen dari novel. Kependekan dari bentuk cerpen harus mampu memberikan pukulan tajam pada pribadi pembaca. Cerpen yang ngelantur dan kabur tidak akan dikategorikan sebagai cerpen yang baik. (Sumardjo, 2017). Cerita pendek haruslah berbentuk padat. Jumlah kata kata cerpen haruslah lebih sedikit ketimbang jumlah kata dalam novel. (Stanton, 2012).

Kondisi keberadaan karya sastra sebagai fakta kemanusiaan yang bersifat semiotik amat perlu diperhatikan. Sebagai fakta kemanusiaan, karya sastra merupakan ekspresi dari kebutuhan tertentu manusia, sedangkan sebagai fakta semiotik karya sastra itu mempunyai ciri khas yang perlu diketahui. (Faruk, 2014).

Menulis karya sastra merupakan kegiatan kreatif yang bermanfaat. Dengan menulis karya sastra, tentunya penulis dapat memberikan kebermanfaatan bagi diri sendiri dan pembacanya. Tidak sedikit penulis karya produktif yang kemudian terkenal karena karya-karya yang diciptakan. Karya sastra yang dimuat di media tidak tentu bisa mendatangkan uang atau royalti bagi penulisnya. Semakin terkenal tentu berpotensi menjadi pembicara untuk mengisi berbagai workshop atau penulisan sastra. Dalam konteks ini tentu menulis sastra bisa mendatangkan keuntungan materi bagi penulisnya dan tentu bisa memberikan kebermanfaatan bagi pembacanya.

Untuk meningkatkan hasil pembelajaran cerpen alternatifnya adalah perlu menerapkan model pembelajaran yang efektif dan menarik. Model pembelajaran sangat penting diperlukan untuk meningkatkan kualitas hasil belajar, agar lebih baik.

Model pembelajaran tentu ada banyak. Salah satu model pembelajaran yang dirasa efektif dalam menarik adalah model pembelajaran sinektik.

Fokus utama dalam pembelajaran sinektif yaitu dengan penggunaan sebuah analogi. Dengan menggunakan analogi peserta didik dapat bermain-main dengan analogi. Siswa bisa berpikir sambil belajar untuk membuat sebuah perbandingan atas metafora, kemudian menggunakan segenap analogi untuk menyelesaikan masalah atau gagasan.

Dalam konteks ini tentu menyelesaikan masalah yang dimaksud adalah mencari ide kreatif untuk menghasilkan karya sastra cerpen yang bagus dan menarik. Setelah dalam ide kemudia siswa menuliskannya dalam bentuk tulisan. Model ini diharapkan dapat menjadi alternatif untuk meningkatkan hasil pembelajaran menulis karya sastra, khususnya cerpen.

Model sinektik dikembangkan oleh Gordon (dalam Joyce dan W., 1968). Ia mendasarkan model sinektis ini pada empat ide yang menentang pandangan lama berkaitan dengan kreativitas. Empat ide yang dimaksud adalah sebagai berikut: (1) Kreativitas sangat penting dalam kehidupan sehari-hari. (2) Proses kreatif bukanlah hal yang misterius. (3) Pertemuan yang kreatif pada hakikatnya sama dalam berbagai bidang yang ditandai oleh proses intelektual yang melatarbelakanginya. (4) Penemuan yang kreatif dari individu dan kelompok pada dasarnya serupa. Inti model sinektik adalah aktivitas metafora, yang meliputi analogi personal, analogi langsung, dan konflik yang dipadatkan. (Joyce dan Weil, 1986: 166-168).

Model sinektik ini memiliki setidaknya memiliki enam tahap, yakni sebagai berikut: (1) Deskripsi kondisi saat ini. "Mahasiswa diminta unuk memaparkan atau mendeskripsikan situasi yang ia amati saat ini. (2) Proses analogi langsung. Mahasiswa mengemukakan berbagai macam analogi atau pengandaian. Kemudian memilihnya salah satu untuk dieksplorasi lebih jauh. (3) Analogi Personal. Mahasiswa menjadikan dirinya sebagai analogi dari keadaan yang dianalogikan pada tahap sebelumnya. (4) Konflik yang dipadatkan, mahasiswa mengambil apa saja yang dipaparkan atau 
dideskripsikan pada fase kedua atau ketiga. Kemudian membuat beberapa konflik yang dipadatkan, dan memilih satu. (5) Analogi langsung. Mahasiswa mengemukakan dan memilih analogi langsung yang lain berdasarkan konflik yang dipadatkan. (6) Pengujian kembali tugas awal. Mahasiswa diarahkan untuk kembali kepada tugas awal atau masalah yang menggunakan analogi yang terakhir atau pada keseluruhan proses sinektik.

Menurut Segers (2000) kualitas karya sastra (cerpen) dapat diketahui dari tujuh aspek, yaitu (1) Imitasi, (2) Fiksionalisasi, (3) Pemakaian Bahasa yang Menyimpang, (4) Violasi (Pelanggaran Sistem norma sastra pembaca, (5) Kompleksitas, (6) Kesatuan, dan (7) Teruji oleh Waktu.

Keterampilan menulis cerpen tentu sangat bermanfaat. Dengan keterampilan menulis karya sastra yang baik, calon guru bahasa Indonesia tentu akan memiliki kelebihan. Mereka tidak hanya sebatas tahu teori menulis karya sastra tapi juga bisa menulis karya sastra dengan baik. Keterampilan ini tentu dapat memberikan kebermanfaatan bagi diri sendiri maupun orang lain.

Bagi penulis pemula, yang baru awalawal belajar menulis terkadang memang memiliki banyak hambatan. Hambatan yang ada tentu bisa hilang asal penulis pemula itu mau untuk praktik secara langsung dengan banyak membaca lalu menulis, menulis, dan menulis.

Meskipun menulis itu merupakan kegiatan yang dianggap sulit, tapi dengan kerja keras, niat, serta memperbanyak praktik langsung menulis tentunya diharapkan hasil karya sastra yang ditulis tentu akan baik. Seandainya masih ada kekurangan dan ada banyak kritik terhadap karya sastra yang dibuat, itu wajar. Hasil masukan dan kritikan tadi tentu dapat dijadikan acuan agar ke depan bisa menghasilkan karya sastra yang lebih baik lagi.

Karya sastra idealnya memberi kontribusi positif bagi pembacanya. Lewat rangkaian kata yang ditata sedemikian rupa-penuh cita rasa, dan unsur simboliskarya sastra memberi pencerahan sekaligus pemenuhan dahaga batiniah pengkonsumsinya (Wibowo, 2013:66).

\section{METODE PENELITIAN}

Penelitian ini merupakan sebuah penelitian yang dilaksanakan dengan menggunakan desain PTK (Penelitian Tindakan Kelas) yang dilakukan selama dua siklus. Penelitian ini termasuk penelitian kualitatif. Tiap-tiap siklus terdiri atas beberapa tahapan Pertama perencanaan, Kedua tindakan, Ketiga observasi, dan Keempat refleksi. Subjek dalam penelitian ini adalah kemampuan menulis cerita pendek mahasiswa Program Studi Penddikan Bahasa dan Sastra Indonesia, FKIP Universitas Muria Kudus. Dipilihnya pengikut Mata Kuliah Ekspresi Tulis sastra kaitannya dengan pembelajaran Menulis Kreatif, khususnya cerpen sebagai subjek penelitian karena fakta bahwa kemampuan menulis mahasiswa masih kurang baik. Di samping itu, perilaku atau sikap mahasiswa dalam mengikuti pembelajaran menulis masih kurang baik, sehingga perlu ditingkatkan.

Waktu dalam melakukan penelitian ini dilakukan selama 4 Minggu. Penelitian ini dilakukan setiap hari Senin di bulan April tahun 2018. Penelitian ini dilaksanakan di gedung J lantai I, Program Studi PBSI FKIP kampus UMK (Universitas Muria Kudus) pada mata kuliah Ekspresi Tulis Sastra Semester V.

Subjek dalam penelitian ini adalah mahasiswa Prodi PBSI (Pendidikan Bahasa dan Sastra Indonesia) FKIP (Fakultas Keguruan dan Ilmu Pendidikan) Universitas Muria Kudus yang mengambil mata kuliah Pilihan, yaitu mata kuliah Ekspresi tulis sastra semester Genap tahun 2018. Mata kuliah pilihan lainnya adalah Ekspresi lisan sastra. Mahasiswa PBSI yang mengambil mata kuliah pilihan ekspresi tulis sastra ada 10 mahasiswa. Mahasiswa yang mengikuti mata kuliah 
ini ada 10 mahasiswa, terdiri dari 9 lakilaki dan satu wanita.

Prosedur penelitan yang digunakan dalam penelitian ini adalah menggunakan Siklus PTK yang dikembangkan oleh Kemmnis dan Mc. Tagart (Arikunto 2010).

\section{Perencanaan (Planning)}

Tahap ini merupakan tahap dimana peneliti mempersiapkan segala keperluan penelitian sebelum melakukan action/ tindakan di lapangan.

\section{Pelaksanaan atau Tindakan (Action)}

Menurut Arikunto (2010) menyatakan bahwa tahap pelaksanaan merupakan bentuk implementasi atau penerapan isi rancangan yaitu dengan menggunakan tindakan kelas.

\section{Pengamatan (Observing)}

Tahap ini merupakan tahap pengumpulan berbagai data yang diamati dari fenomena yang terjadi pada saat perlakuan atau pemberian tindakan itu berlangsung.

\section{Refleksi (Reflecting)}

Pada langkah ini peneliti mengkaji, melihat, dan mempertimbangkan atas hasil atau dampak dari tindakan dari berbagai kriteria.

Teknik pengumpulan data yang digunakan dalam penelitian ini dilakukan dengan tes, wawancara, pengamatan/ observasi, dan dokumentasi. teknik tersebut diuraikan sebagai berikut.

1. Tes

Tes digunakan untuk mengumpulkan informasi tentang hasil penulisan cerita pendek berkonteks multikultural pada mata kuliah ekspresi tulis sastra. Tes dilakukan pada saat awal penelitian, pada akhir setiap tindakan, selain itu pada akhir setelah diberikan serangkaian tindakan pada siklus I dan juga siklus II.

2. Wawancara

Wawancara dimaksudkan untuk menggali kendala mahasiswa dalam pembelajaran menulis cerpen, interaksi mahasiswa dalam proses pembelajaran berlangsung, yang mungkin diperoleh dari hasil pekerjaan mahasiswa.

\section{Pengamatan/observasi}

Pengamatan atau observasi dilaksanakan untuk melihat aktivitas mahasiswa, keaktifan mahasiswa dalam pembelajaran menulis cerita pendek.

\section{Dokumentasi}

Dokumen data dalam penelitian ini meliputi sumber data dalam penelitian berupa catatan yang relevan dengan penelitian. Data tambahan lain diperoleh dari foto dokumentasi penelitian tentang penulisan cerpen.

Teknik analisis data ini dilakukan selama pelaksanaan penelitian dari awal sampai akhir penelitian. Berdasarkan analisis data yang dilakukan penelitian, rincian analisis data yaitu sebagai berikut:

Analisis hasil observasi

Data saat observasi menggunakan skala penilaian penjelasan rentang nilai dalam bentuk angka $(4,3,2,1)$ untuk penilaian pada proses pembelajaran yang berarti angka 4 = baik, $3=$ baik, $2=$ cukup, dan 1 . Adapun kriteria hasil belajar mahasiswa terkait penilaian penulisan cerpen adalah sebagai berikut.

Tabel 1. Pedoman Penilaian Cerpen

\begin{tabular}{ll}
\hline No & Aspek Penilaian \\
\hline 1 & Tema \\
\hline 2 & Kelengkapan unsur pembangun \\
\hline 3 & Keterpaduan unsur pembangun \\
\hline 4 & Kemenarikan \\
\hline 5 & Penggunaan bahasa \\
\hline
\end{tabular}

\section{HASIL DAN PEMBAHASAN}

Keterampilan mahasiswa Program Studi Pendidikan Bahasa dan Sastra Indonesia (PBSI) FKIP Unversitas Muria Kudus bisa dikatakan masih rendah. Dalam Prasiklus kemampuan menulis cerpen pada mata kuliah ekspresi tulis sastra masih kurang, belum tuntas semua. 
Aspek yang dinilai adalah pertama tema, kelengkapan unsur pembangun, keterpaduan unsur pembangun, kemenarikan, dan penggunaan bahasa. Dari total lima kriteria tersebut, mendapatkan rata-rata 50,6. Selain nilai yang masih kurang, aktivitas pembelajaran mahasiswa dalam mengikuti mata kuliah juga kurang semangat terhadap pembelajaran menulis karya sastra seperti menulis cerpen.

Berdasarkan hasil prasiklus tersebut, maka diterapkan model sinektik untuk membantu mahasiswa PBSI FKIP UMK dalam menulis cerita pendek yang baik. Maka dilakukanlah PTK selama dua siklus. Hasil uji kemampuan menulis karya sastra cerpen siklus I menunjukkan bahwa kemampuan menulis cerpen mahasiswa tergolong kurang dengan hasil skor rata-rata yaitu 60,42 dan mayoritas mahasiswa pun berada dalam kategori cukup. Hasil selengkapnya dapat dilihat pada tabel berikut ini.

Tabel 2 Hasil Tes Keterampilan Menulis cerpen Siklus I

\begin{tabular}{|l|l|l|l|}
\hline No & Aspek Penilaian & $\begin{array}{l}\text { Skor } \\
\text { Rata- } \\
\text { rata }\end{array}$ & Kategori \\
\hline 1 & Tema & 57,7 & Kurang \\
\hline 2 & $\begin{array}{l}\text { Kelengkapan unsur } \\
\text { pembangun }\end{array}$ & 57,6 & Kurang \\
\hline 3 & $\begin{array}{l}\text { Keterpaduan unsur } \\
\text { pembangun }\end{array}$ & 61 & Kurang \\
\hline 4 & Kemenarikan & 61,7 & Kurang \\
\hline 5 & Penggunaan bahasa & 64,1 & Kurang \\
\hline & Rata-rata & 60,42 & \\
\hline
\end{tabular}

Data tabel 2 menunjukkan bahwa hasil keterampilan menulis cerpen klasikal mahasiswa mencapai nilai rata-rata 60.42 atau kaegori sedang. Dari 10 mahasiswa kategori sangat dengan nilai antara 85-100 belum ada mahasiswa yang mencapainya atau sebesar $0 \%$. Selanjutnya sebanyak 3 mahasiswa atau sebesar $30 \%$ memperoleh kategori baik yaitu dengan nilai antara 75 84. Selebihnya 5 mahasiswa atau sebesar
$50 \%$ memperoleh kategori sedang dengan nilai antara 0-59.

Jika dilihat secara spesifik, perolehan nilai mahasiswa sebagian besar masih kategori sedang. Selama mengikuti pembelajaran perilaku mahasiswa diamati. Hasil observasi dan pengamatan kepada mahasiswa menunjukkan kualitas perilaku mahasiswa dalam praktik menulis cerpen dalam kategori kurang aktif. Untuk itu perlu berbagai upaya lagi agar kemampuan menulis cerpen mahasiswa menjadi lebih baik. Keterampilan menulis tentu tidak datang dengan sendirinya, perlu dilatih dan diasah dengan baik. Keterampilan yang sering dilatih tentu kelas akan menjadi lebih terasah sehingga diharapkan tahap selanjutnya bisa lebih baik lagi.

Tabel 3 Hasil Penilaian Keterampilan Menulis cerpen Siklus I

\begin{tabular}{|l|l|l|l|l|l|}
\hline No & Kategori & $\begin{array}{l}\text { Rentang } \\
\text { Nilai }\end{array}$ & $\begin{array}{l}\text { Freku- } \\
\text { ensi }\end{array}$ & $\begin{array}{l}\text { Persen- } \\
\text { tase }\end{array}$ & $\begin{array}{l}\text { Rata- } \\
\text { rata }\end{array}$ \\
\hline 1 & $\begin{array}{l}\text { Sangat } \\
\text { baik }\end{array}$ & $\begin{array}{l}85- \\
100\end{array}$ & 0 & 0 & $\begin{array}{c}\text { Rata-rata } \\
60,42 \\
\text { Kategori } \\
\text { kurang }\end{array}$ \\
\hline 2 & Baik & $75-84$ & 3 & 30 & \\
\hline 3 & Cukup & $60-74$ & 2 & 20 & \\
\hline 4 & Sedang & $0-59$ & 5 & 50 & \\
\hline & & & 10 & 100 & \\
\hline
\end{tabular}

Setelah dilakukan penelitian tindakan kelas pada siklus II menunjukkan adanya suatu peningkatan hasil penelitian yang cukup signifikan. Peningkatan keterampilan menulis yang cukup signifikan itu tentu sangat positif. Hasil yang positif ini tentu menjadi indikator keberhasilan menulis bagi peserta didik. Hal itu menunjukkan bahwa kemampuan menulis kalau diasah dengan baik dan ditunjang dengan model pembelajaran yang menarik tentu dapat meningkatkan kualitas pembelajaran. 
Pada saat siklus I nilai rata-rata kualitas menulis cerpen adalah 60.42 sedangkan pada siklus II terjadi peningkatan dengan nilai 80.18. peningkatan keterampilan menulis cerpen disebabkan oleh beberapa faktor, yaitu faktor dari dalam internal dan faktor dari luar eksternal. Mahasiswa mampu menulis cerpen dengan baik karena penerapan metode sinektik.

Mahasiswa juga merasa senang dengan penerapan model tersebut. Selain kualitas pembelajaran meningkat, perilaku mahasiswa di kelas juga mengalami peningkatan yang positif. Hasil keterampilan menulis cerita pendek pada siklus II dapat dilihat hasilnya pada tabel 4 berikut.

Tabel 4 Hasil Penilaian Menulis cerpen Siklus II

\begin{tabular}{|c|c|c|c|c|c|}
\hline $\begin{array}{l}\mathbf{N} \\
\mathbf{0}\end{array}$ & $\begin{array}{l}\text { Kateg } \\
\text { ori }\end{array}$ & $\begin{array}{l}\text { Renta } \\
\text { ng } \\
\text { Nilai }\end{array}$ & $\begin{array}{l}\text { Fre } \\
\text { k } \\
\text { uen } \\
\text { si }\end{array}$ & $\begin{array}{l}\text { Per } \\
\text { se } \\
\text { ntas } \\
\text { e }\end{array}$ & $\begin{array}{l}\text { Rata- } \\
\text { rata }\end{array}$ \\
\hline 1 & $\begin{array}{l}\text { Sangat } \\
\text { baik }\end{array}$ & $\begin{array}{l}85- \\
100\end{array}$ & 2 & 20 & \multirow{5}{*}{$\begin{array}{l}\text { Rata- } \\
\text { rata } \\
80,18 \\
\text { Kateg } \\
\text { ori } \\
\text { kuran } \\
\text { g }\end{array}$} \\
\hline 2 & Baik & $75-84$ & 7 & 70 & \\
\hline 3 & Cukup & $60-74$ & 1 & 10 & \\
\hline 4 & $\begin{array}{l}\text { Sedan } \\
\mathrm{g}\end{array}$ & $0-59$ & 0 & 0 & \\
\hline & & & 10 & 100 & \\
\hline
\end{tabular}

Perbandingan hasil belajar mahasiswa dalam menulis cerita pendek dalam pelaksanaan pembelajaran menggunakan model sinektik pada Prodi PBSI FKIP Universitas Muria Kudus, setelah dilaksanakan tindakan siklus I dan Siklus

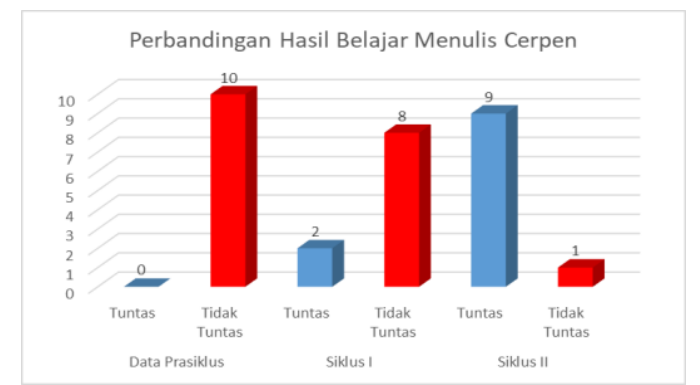

II dapat digambarkan dalam grafik sebagai berikut:

Grafik 1 Perbandingan Hasil Penelitian Menulis Cerpen Prasiklus, siklus 1, dan Siklus II
Permasalahan pembelajaran menulis cerpen mahasiswa dapat ditingkatkan dengan penerapan model sinektik sosial. Perbaikan yang dilakukan dalam pembelajaran dapat berpengaruh positif untuk meningkatkan kualitas pembelajaran mahasiswa. Berdasarkan analisis data yang telah dilakukan, dapat dijelaskan bahwa perilaku mahasiswa dalam menulis cerpen mengalami peningkatan yang positif. Peningkatan yang positif tersebut tentu sangat menggembirakan. Suasana kelas yang semula agak pasif berubah menjadi aktif dan tidak membosankan.

Aktivitas Pembelajaran Mahasiswa PBSI UMK menjadi objek dalam penelitian ini. Mahasiswa berperan sangat penting sekali dalam penelitian ini. Perilaku atau aktivitas pembelajaran mahasiswa mengalami peningkatan dari Siklus I hingga siklus II. Sehingga Model pembelajaran model sinektik yang diimplementasikan mampu meningkatkan aktivitas mahasiswa.

\section{SIMPULAN}

Berdasarkan pada hasil penelitian dapat disimpulkan bahwa proses pembelajaran keterampilan menulis cerita pendek dengan menggunakan metode sinektik sosial berkonteks multikultural dapat meningkatkan hasil belajar mahasiswa pada mata kuliah ekspresi tulis sastra. Indikator keterampilan menulis cerpen yang mencakup (a) tema, (b) kelengkapan unsur, (c) keterpaduan antarunsur, (d) kemenarikan, (e) penggunaan bahasa, mengalami peningkatan.

Peningkatan kualitas hasil belajar dalam menulis cerita pendek terbukti meningkat hal itu terlihat dari skor nilai rata-rata pratindakan sebesar 50,6 kategori 
kurang. Pada saat siklus I rata-rata sebesar 60,42 pada siklus II naik menjadi 80,18 degan kategori baik. Selain kualitas pembelajaran meningkat, perilaku mahasiswa dalam pembelajaran menulis cerita pendek juga menjadi lebih baik.

\section{DAFTAR PUSTAKA}

Ahsin, Muhammad Nur. 2016. Peningkatan Keterampilan Menulis Karangan Narasi dengan Menggunakan Media Audiovisual dan Metode Quantum Learning. Jurnal Refleksi Edukatika. Vol. 6 No. 2.

Arikunto, S. 2016, Penelitian Tindakan Kelas. Jakarta: PT. Bumi Aksara.

Faruk. 2014. Metode Penelitian Sastra. Yogyakarta: Pustaka Pelajar.

Joyce, B. dan M. Weil. 1986. Model of Teaching. New Jersey: Prentice-Hall, Inc.

Nuryatin, Agus dan Retno Purnama Irawati. 2016. Pembelajaran Menulis Cerpen. Semarang: Cipta Prima Nusantara.

Pramujiono, Agung. 2015. "Pembelajaran Sastra Multikultural: Menumbuhkan Empati dan Menemukan Jatidiri Bangsa Melalui Pemahaman Keanekaragaman Budaya.” Jurnal Sosiohumanika, Volume 8, Nomor 2.

Segers, R. T. 2000 (Ed.) 1984. Kamus Istilah Sastra. Jakarta: Gramedia.

Setyaningsih, Nas Haryati. 2010. Peningkatan Keterampilan Menulis Cerpen Mahasiswa Jurusan Bahasa dan Sastra Indonesia dengan Model Sinektiks yang Dikembangkan. Jurnal Lingua. Universitas Negeri Semarang. Vol 6. No. 2

Stanton, Robert. 2012. Teori Fiksi. Yogyakarta: Pustaka Pelajar.

Sumardjo, Jacob. 2017. Menulis Cerpen. Yogyakarta: Pustaka Pelajar.

Wibowo, Agus. 2013. Pendidikan Karakter Berbasis Sastra. Yogyakarta: Pustaka Pelajar. 